\title{
Equitable Engagement in STEM: Using E-textiles to Challenge the Positioning of Non-dominant Girls in School Science
}

\author{
Kristin A. Searle \\ Utah State University \\ U.S.A. \\ Colby Tofel-Grehl \\ Utah State University \\ U.S.A. \\ Janet Breitenstein \\ Utah State University \\ U.S.A.
}

Abstract: This paper examines how working with sewable, programmable electronics embedded in textiles (e-textiles) impacted the self-perceptions and actions of two middle school girls from non-dominant communities as they navigated their place within science class. Using analytic induction (Erickson, 1986), we explore the phenomena around their experiences and the influence of their teachers' perceptions. Findings indicate that the personalizable nature of e-textiles created a meaningful opportunity for students to engage in science class in a new way.

Keywords: identity, STEM, e-textiles, science, engagement

\author{
Background \\ Our Approach \\ Methods \\ Findings \\ Discussion \\ Notes \\ Acknowledgments \\ References \\ Author Contact
}

Educational technology is increasingly seen as a tool for improving instruction and broadening participation by connecting students' in-school learning to their out-of-school lives. However, the promise of educational technology often remains unfulfilled (Cuban, 2001). Three key issues around educational technology and equity led us to focus on integrating meaningful educational technology experiences into core content classes rather than elective or out-of-school spaces. First, while the so-called digital divide has narrowed, access to technology and especially the Internet remains disproportionately limited for low-income students, students of color, and rural students (Perrin \& Duggan, 2015). Few school districts have a plan in place for students to access technology outside of school (https://cosn.org/digitalequity). While libraries and afterschool clubs have attempted to fill this void (Barron, Gomez, Pinkard, \& Martin, 2014; Hoffman, Bertot, \& 
Davis, 2012; Horrigan, 2016), participation in these spaces is voluntary and there are many barriers to access (Acholonu, Pinkard, \& Martin, 2015; DiSalvo, Reid, \& Roshan, 2014).

A second issue around educational technology and equity is identification. Many female and non-dominant students do not see themselves as belonging in science, technology, engineering, and math (STEM) spaces, especially in school contexts (Archer et al., 2012; Tan, Calabrese Barton, Kang, \& O'Neill, 2013). Promoting disciplinary identification has become as important as access to and participation in meaningful, technology-enriched learning experiences (Bell, Van Horne, \& Cheng, 2017). Activities that connect to students' interests and experiences, such as those promoted by the Maker Movement (Peppler, Halverson, \& Kafai, 2016a, 2016b), have proven especially promising for broadening participation in STEM. Although these activities primarily take place in voluntary, out-of-school spaces (Calabrese Barton, Tan, \& Greenberg, 2017; Pinkard, Erete, Martin, \& McKinney de Royston, 2017), there is increasing recognition of the importance of moving making activities into school classrooms (Blikstein, Kabayadondo, Martin, \& Fields, 2017; Fields, Kafai, Nakajima, Goode, \& Margolis, 2018).

A third issue is how technology is used in educational environments. Research has shown that school knowledge is often determined by social class, meaning that students in high- and middle-income areas are taught to be critical thinkers and producers of technology while students in low-income areas are taught to be uncritical consumers of technology (Anyon, 1981; Buendia, Ares, Juarez, \& Peercy, 2004; Warschauer \& Matuchniak, 2010). While there are certainly exceptions, such as the use of the Exploring Computer Science curriculum in the Los Angeles Unified School District (Margolis, Ryoo, Moreno, Lee, Goode, \& Chapman, 2012), this program resulted from awareness of inequities in technology use that kept girls and non-dominant students "stuck in the shallow end" of computing (Margolis, Estrella, Goode, Holme, \& Nao, 2008). Many students in Title 1 schools, classified as schools where $40 \%$ or more of students receive free and reduced lunch (and often schools with high populations of minority students and English Language Learners), primarily use technology as a substitute for pen and pencil, completing worksheets on a computer or engaging with software intended to remediate math and literacy skills (Margolis et al., 2008). In contrast, students in middle class areas are often engaged in transformative uses of technology to solve real-world problems, such as developing an alert system for police officers to know when their dogs are overheating in the hot summer months (Craft, 2015). We believe that all students should have access to these kinds of experiences through classroom integration of hands-on, project-based learning. Research highlights the point that such "hands-on, minds-on" (Rose, 2005) activities are likely to connect to the kinds of everyday making and tinkering practices that are economically necessary in many non-dominant communities (Vossoughi, Hooper, \& Escude, 2016). Well-designed making activities draw on learners' funds of knowledge (González, Moll, \& Amanti, 2005) to create connections between home and school and, in so doing, may lessen the STEM identity gap experienced by many non-dominant students (Tan et al., 2013). Further, we know that becoming producers of technology is central to full civic and computational participation (Kafai \& Burke, 2014). 
In this article, we explore two cases of non-dominant girls making with electronic textiles materials in science classes to understand how such projects can provide access to an inquiry-driven science curriculum and to innovative technology experiences while lessening the STEM identity gap for non-dominant girls. Electronic textiles materials consist of a small, flat, programmable microcontroller, such as the LilyPad Arduino; a power source (battery); and a variety of sewable sensors and actuators, such as LED lights (see Figure 1). These high-tech materials are integrated with everyday craft items, like felt and embroidery floss. Using a needle and special conductive thread, the components are sewn together to create a functional circuit embedded in a fabric item, such as a backpack or t-shirt. Such projects align well with Next Generation Science Standards (NSB, 2013) and the Computer Science Teachers Association standards (CSTA, 2017). They also tend to be more accessible to non-dominant students because of the variety of points of entry into science and computing (Searle \& Kafai, 2015a). We ask two specific questions: How do non-dominant girls engage with e-textiles projects and materials in science classrooms? How do such engagements shift their perceptions and their teachers' perceptions of what STEM is and who can do it?

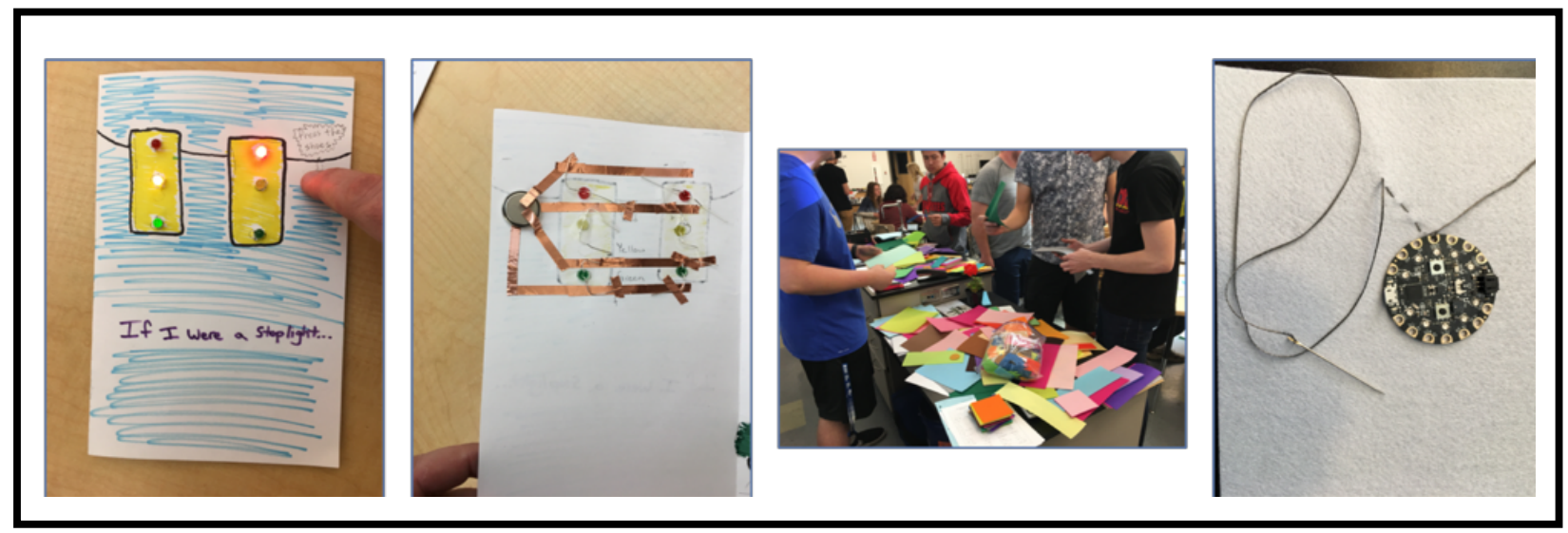

Figure 1: A paper circuit card using copper tape, LED lights and a battery, students choosing from a colorful array of felt, and a microcontroller sewn into felt using a needle and conductive thread.

\section{Background}

Building on the themes we identified above-access to, identification with, and meaningful use of technology - we argue that e-textiles materials present an opportunity to equitably engage non-dominant students in classroom-based STEM learning. We conceptually frame our analysis at the intersections of culturally responsive schooling, STEM identity development, and constructionism. At its most basic, culturally responsive schooling "makes sense" to learners from a particular cultural group (Klug \& Whitfield, 2003, p. 151). Drawing on Geneva Gay's (2000) work, Klump and McNeir (2005) note that "culturally responsive education recognizes, respects, and uses students' identities and backgrounds as meaningful sources for creating optimal learning environments" ( $p$. 3). Building on ethnomathematics (Davidson \& Miller, 1998) as a form of culturally responsive schooling, culturally responsive computing has emerged as a field of inquiry (Eglash, Bennett, O’Donnell, Jennings, \& Cintorino, 2006; Eglash, Gilbert, \& Foster, 
2013). Most recently, Scott and colleagues (2015) have defined culturally responsive computing as follows:

1. All learners are capable of digital innovation.

2. The learning context supports transformational use of technology.

3. Learning about one's self along various intersecting sociocultural lines allows for technological innovation.

4. Technology should be a vehicle in which students reflect and demonstrate understanding of their intersectional identities.

5. Barometers for technological success should consider who creates, for whom, and to what ends, rather than who endures socially and culturally irrelevant curriculum. (pp. 420-421)

In this article, we take up this more nuanced definition of culturally responsive computing. We also recognize that the availability of standards-aligned science and computing content in K-12 public schools is central to equity and student success.

We focus our analysis on the fourth tenet of Scott and colleagues' (2015) definition of culturally responsive schooling, the idea that technology should be a vehicle through which students can express and explore their intersectional identities. In particular, we focus on girls and non-dominant students from particular linguistic and cultural backgrounds. Recent research suggests that perhaps more significant than the participation gap in STEM fields is an identity gap where girls and non-dominant students do not see themselves as belonging in STEM fields (Searle \& Kafai, 2015a; Tan et al., 2013). Recognizing that identities are worked out in and through practice in contentious local contexts and in relation to enduring historical struggles (Bourdieu, 1977; Holland \& Lave, 2001), it is possible to design learning activities and environments that support particular kinds of identities (Bell, Van Horne, \& Cheng, 2017), including STEM identities.

The purposeful amalgamation of craft, circuitry, and computing in e-textiles is intended to complicate our cultural understandings of highly gendered domains (Buechley, 2006). Crafting is typically seen as "low tech" women's work, while engineering and computer science have come to be seen as "high tech" men's work (Ensmenger, 2010; Oldenziel, 1999). Through the combination of high (circuits, programming) and low (crafting, sewing) technology, e-textiles projects draw upon different traditions in the gendered nature of the work, thus allowing for multiple points of connection to the lived experiences and identities of a diverse range of students. The e-textiles learning activities reported in this article are designed to support particular kinds of identities-in-practice for girls and non-dominant students engaging with STEM and computing.

Finally, we frame our work in terms of a fundamental belief in constructionism, the idea that students learn best when constructing physical or digital artifacts with an authentic audience in mind (Papert, 1980). Thus, in each of the e-textiles projects students are tasked with creating a physical artifact and, in more sophisticated projects, an accompanying computer program. Our overall approach to making projects in science classrooms is to have students make physical and digital artifacts that support expression and exploration of their intersectional identities. We do so through leveraging familiar practices, family, and other out-of-school interests and hobbies to support STEM identity development for girls and non-dominant students. 


\section{Our Approach}

Table 1

Connecting E-textiles Activities to the Next Generation Science Standards

\begin{abstract}
4-PS3: Energy are likely.

Performance Expectation

4-PS3-2. Make observations to provide evidence that energy can be transferred from place to place by sound, light, heat, and electric currents.
\end{abstract}

www.nextgenerationscience.org/topic-arrangement/4energy

The chart below illustrates one possible set of connections between the e-textiles curriculum mentioned in this article and the NGSS (National Science Board, 2013). Other valid connections

\section{Science and Engineering Practices \\ Planning and carrying out investigations \\ Constructing explanation and designing solutions}

\section{Disciplinary Core Idea}

PS3.B: Conservation of energy and energy transfer

- Energy can also be transferred from place to place by electric currents, which can then be used locally to produce motion, sound, heat, or light.

Crosscutting Concepts

Energy and matter

Cause and effect

\section{Connections to Classroom Activity}

- Students build circuit models using a wide range of materials (e.g. copper tape, conductive thread, metal snaps) that allow them deeper understanding of how electric currents work.

- Students build models of circuits, compare circuit designs, compare the effectiveness of types of circuits, and construct models of circuits that demonstrate an understanding of electric current.

- Students design and build electric circuits using a variety of materials and systems to transfer energy and produce light.

- Students explore various techniques in which energy can be transferred in various ways and between objects

- Students work to understand the relationships between parts of circuits and how changes affect output.

\section{Design of E-textiles Curriculum}

Moving e-textiles activities from out-of-school and elective spaces (Fields et al., 2018; Kafai, Fields, \& Searle, 2014) into school spaces does not come without its challenges. To be included in core content areas, e-textiles projects must be standardsaligned. They must also be cost- and time-effective within the constraints of the school day, and teachers must be prepared to implement projects in their classrooms. We developed a curriculum and accompanying professional development that takes a faded scaffolding approach to introduce teachers and students to e-textiles making activities, gradually removing instructional supports as they become more comfortable with the content (Tofel-Grehl, Searle, \& Feldon, 2018). Projects are primarily aligned with the Next Generation Science Standards (NGSS) (see Table 1), but also align with K-12 computer 
science standards (CSTA, 2017). Students start with using a number of circuit templates, copper tape, LED lights, and coin cell batteries to create functional paper circuits. Students then use the same materials to create their own greeting cards. This project allows us to introduce basic circuitry in an aesthetic context without complicated sewing (see Figure 2) and at a manageable cost (\$1/student).

From there, students move onto sewing e-textiles bracelets, including a snap closure that functions as a switch. This provides us with an opportunity to introduce some of the technicalities of working with conductive thread while also furthering students' circuitry knowledge. To eliminate some of the challenges in working at the intersections of craft, circuitry, and computing, we have also developed an activity called the bracelet hack (Searle, Tofel-Grehl, \& Allan, 2016) where students attach their simple circuit snap bracelet to a microcontroller using alligator clips to learn to program it. This means that students must at first only deal with the intersection of craft and circuitry; then, when they know their circuit is functional, they move on to programming. The activity setup also ensures that any errors in the second stage are the result of flawed code rather than problems with the construction of the circuit.

In addition, teachers have a classroom set of microcontrollers that are reusable from project to project, so the cost of e-textiles projects is reduced significantly (\$5/student). Once students have a grasp of how to work with e-textiles materials and a basic understanding of circuitry and code, there are a number of more advanced projects that their teacher may choose to incorporate depending on time limitations.

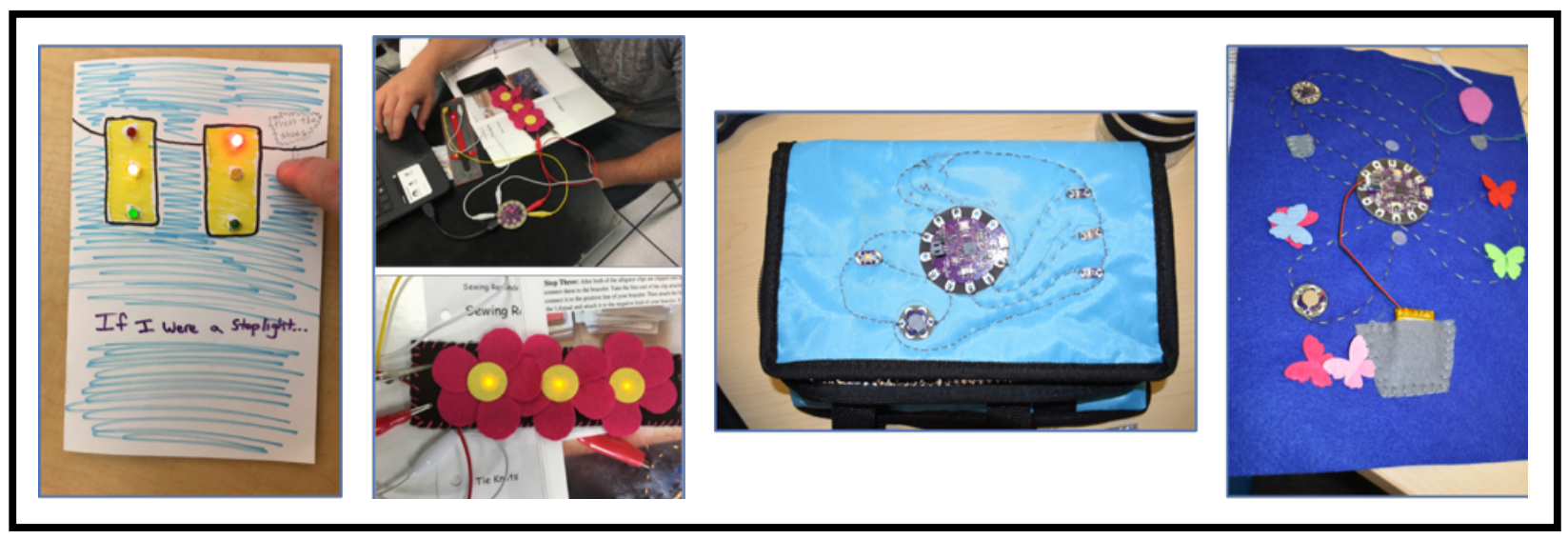

Figure 2 (from L to R): Paper Circuit Card, Bracelet Hack and Aesthetic Bracelet, Lunchbox, and Slouch-Sensing T-Shirt.

In each of the projects, a number of design constraints are included. In the etextiles curricular unit, we balance a need for aesthetics with a need for scaffolded learning opportunities and standards alignment. We foreground aesthetics in the paper circuit and bracelet projects and then move to a template-based model for the lunchbox, returning to an aesthetics focus with the t-shirt project. Students who finish early can personalize their projects while others can do so outside of classroom time. We have not observed differences in student engagement or STEM interest as a result of these design constraints. 1 


\section{Methods}

\section{Site and Context of Implementation}

The data presented here come from a larger study of teacher professional development and implementation of standards-aligned e-textiles curriculum in secondary science classrooms across the western United States. We focus on a subset of classrooms selected for their diverse populations, defined as encompassing cultural, ethnic, racial, linguistic, and socioeconomic diversity. Many schools in the region are predominantly White and middle class, without a significant percentage of minority students. In defining the subset of schools for collecting student interview data, we looked at schools where more than $25 \%$ of students self-identified as not of the dominant culture. This resulted in a sample of 10 secondary science classrooms, or 280 students. Approximately 90 of the students were female and 10 agreed to be interviewed. Of the subset of 10 female students for whom we had interview data, four self-identified as members of non-dominant populations. We present two case studies (Stake, 1995; Yin, 2018), selected because their experiences represent themes that we saw across nondominant girls in our data set. Our analysis is guided by the following questions:

1. How do non-dominant female students engage with e-textiles projects and materials in science classrooms?

2. How do such engagements shift their perceptions and their teachers' perceptions of what STEM is and who can do it?

To protect participants' privacy, names of sites and individuals are pseudonyms.

\section{Sites}

Cartography Central Middle School. The first student case comes from Cartography Central Middle School (CCMS), a rural school in the western continental United States. A local public middle school, CCMS served approximately 500 students annually when data were collected. Approximately $62 \%$ of students are White, $36 \%$ are Latinx, and $2 \%$ are of other racial and ethnic backgrounds. CCMS served an economically diverse population; $26 \%$ of students receive free and reduced lunch assistance. Recently $73 \%$ of students scored in the proficient or above range in both their mathematics and reading standardized test scores. Nearly $75 \%$ of teachers in the school are White. CCMS espouses a mission of ensuring that all students have the foundation to be successful and meet their potential.

Tikik and Ka Pae Charter Middle School. The second student comes from Tikik and Ka Pae Charter Middle School (TKPCMS), a rural, high needs (as determined by the state) school outside of the continental United States, which served 250 students annually at the time of data collection. The school served a population of nearly $75 \%$ Indigenous students, and $50 \%$ of students received free and reduced lunch. Many of the nonIndigenous students at the school were children of employees of a local technology company. Teacher and administrator demographics at the school differed dramatically from those of the students. Approximately $80 \%$ of teachers were White and had moved 
to the school's location as adults. TKPCMS possessed a central mission to engage students in learning through an honoring and integration of Indigenous culture.

\section{Participants}

Students. Out of the many students represented in our larger data set, we chose the two case studies (Stake, 1995) presented here because they were representative of the experiences of non-dominant female students in our larger data set. At the time of data collection, Jessi was a 14-year old Latina girl living in a rural town of approximately 10,000. Teachers reported she was "respectful and quiet" during class and received good grades. A child of immigrant parents, Jessi spoke English as her second language, having come to the United States around the time of kindergarten. Jessi tended towards the quiet, studious side of the middle school spectrum. Teachers referred to her as "quiet and focused" or "hardworking and sweet." While English was not her native language nor spoken at home, Jessi spoke English clearly. When asked about her education, Jessi stated, "I go to school and do my best. Sometimes I do better than others." Multiple teachers shared that Jessi was, in their opinions, a high performing student who completed her assigned work regularly. Jessi experienced e-textiles during her normal eighth grade science class as part of a unit on electricity and energy.

At the time of data collection, Kai was a 13-year-old girl who had attended TKPCMS for a year prior to her enrollment in the study. Her Indigenous heritage permeated her conversations and relationships. She had lived in the same town with her mother for her entire life. Kai's summer school science teacher described her as a "sometimes nice but disengaged and flighty girl," and TKPCMS teachers broadly saw her as a low performing student. An outgoing and socially popular girl, Kai presented herself with the bravado and false confidence typical of adolescent young women of her stature among their peer groups. A dual language speaker, Kai spoke both English and her family's native language. At home, English was the primary language spoken by everyone except her grandmother. Kai learned science content through e-textiles during a summer school science class.

Teachers. It would be impossible to discuss perceptions of students without noting the agency of the teachers involved. Jessi's teacher, Ms. Lazel, had taught 8th grade science at CCMS for over 10 years. A White woman in her late thirties, Ms. Lazel played a leadership role in her school science department because of her seniority and expertise. She had taught Jessi the prior semester in her science class, as well as the semester in which the e-textiles unit was implemented. Ms. Lazel did not choose to engage with etextiles of her own accord but had been required to do so as her school and district adopted that curricular approach after the success of a pilot implementation in the district. While she was a willing participant in our research, she was openly anxious and cautious about using e-textiles materials and activities to teach science.

Kai's teacher, Ms. Massada, had taught at TKPCMS for several years and was considered a master teacher. A White woman in her fifties, Ms. Massada was national board certified in several areas and had taught Kai the prior school year as well as during the summer school science class in which the e-textiles curriculum was implemented. 
Each e-textiles class unit lasted three weeks and consisted of approximately 600 minutes of class time.

\section{Research Team}

We were participant observers (Wolcott, 1999) in school spaces, sometimes sitting in the back of class and observing and other times teaching the class. As with any qualitative work employing ethnographic methods (Hammersley \& Atkinson, 2007), we recognize that our observations were partial and did not capture everything happening in the classroom. We also acknowledge that our positionality inevitably influenced the data collected. All members of the research team are White. All authors are White women. Tofel-Grehl has extensive experience as a classroom science teacher and prepares preservice teachers to work in diverse contexts. Searle has worked in and with Indigenous communities and their schools for more than a decade. Breitenstein is an elementary school teacher and doctoral student. In both communities, we were considered outsiders. These lenses influenced how we interacted with research participants and how they interacted with us (Brayboy \& Deyhle, 2000).

It is also important to acknowledge the relationship between the researcher team and our partners. CCMS is a school in which we have conducted research before. Our prior successful work with this school regarding e-textiles made the current collaboration possible.

Our relationship with TKPCMS took two years to establish. Through a mutual associate, the lead of the research team worked with the school's head administrator to build the collaboration. Within the TKPCMS classroom, the researchers co-taught some sections of the class as models for the classroom teacher; however, this was not the case in Kai's class.

\section{Data Collection and Analysis}

In keeping with the interpretivist paradigm, we conducted classroom observations recorded in field notes (Emerson, Fretz, \& Shaw, 2011) and interviews (See Table 2). Teacher interviews were formal and audio-recorded. They were conducted privately and away from the classroom to ensure teacher comfort and student privacy. Student interviews were informal and documented in field notes, allowing for a more casual, open dialog. We also collected relevant documents, such as teacher lesson plans, and documented teacher- and student-produced e-textiles artifacts through photographs.

Based on the phenomenological belief that reality cannot be ultimately separated from the person experiencing it, we analyzed data collected for this study using a holistic approach from which assertions could be made about the personalized phenomenon being observed. Specifically, we sought to understand the phenomenological differences of students from non-dominant cultures as they engaged in learning through e-textiles. 
Table 2

Data Collection Overview

\begin{tabular}{|l|l|l|l|l|}
\hline $\begin{array}{c}\text { Data } \\
\text { Source }\end{array}$ & $\begin{array}{c}\text { Observations } \\
\text { (documented in } \\
\text { hourly field notes) }\end{array}$ & $\begin{array}{c}\text { Interviews } \\
\text { (formal \& } \\
\text { informal) }\end{array}$ & \multicolumn{1}{|c|}{ Documents } & \multicolumn{1}{|c|}{ Artifacts } \\
\hline CCMS & $\begin{array}{l}40 \text { days of classroom } \\
\text { instruction, six hours } \\
\text { each day. }\end{array}$ & $\begin{array}{l}1 \text { teacher } \\
\text { interviewed } \\
\text { multiple times. } \\
8 \text { students } \\
\text { interviewed. }\end{array}$ & $\begin{array}{l}\text { 20 days of lesson } \\
\text { plans, emails, } \\
\text { school policy } \\
\text { documents. }\end{array}$ & $\begin{array}{l}\text { Photos of paper } \\
\text { circuits, bracelet } \\
\text { projects, and } \\
\text { lunchboxes. }\end{array}$ \\
\hline TKPCMS & $\begin{array}{l}\text { 20 days of classroom } \\
\text { instruction, six hours } \\
\text { each day. }\end{array}$ & $\begin{array}{l}1 \text { teacher } \\
\text { interviewed } \\
\text { multiple times. } \\
2 \text { students } \\
\text { interviewed. }\end{array}$ & $\begin{array}{l}\text { 2 days of lesson } \\
\text { plans, emails, } \\
\text { school policy } \\
\text { documents. }\end{array}$ & $\begin{array}{l}\text { Photos of paper } \\
\text { circuits, bracelet } \\
\text { projects, and } \\
\text { lunchboxes. }\end{array}$ \\
\hline
\end{tabular}

In this article, we draw primarily from field notes, interview transcripts, and photographs of student work. These artifacts were analyzed repeatedly and iteratively as they were collected to delve into both the macro and micro interactions occurring within the phenomenon. Analytic induction was used as the method of data analysis (Erickson, 1986). Within the model of analytic induction, empirical assertions are developed during the data collection process/time period, followed by a warrant that would account meaningfully for the phenomena observed. The researchers must then scour the data for instances that both confirm and call into question these assertions. The current data set, comprising interviews, documents, and observations, was read multiple times to generate the two specific assertions that came together to form a holistic understanding of the phenomena being documented. Vignettes, quotes, and a table are all offered as part of the evidentiary warrant in support of these assertions (See Table 3).

Table 3

Analytic Induction Structures and Exemplars

Observation/s of
student
Jessi, and other Latinas,
did not engage in hands
on science activities that
were optional. However,
during e-textiles she, and
others, were highly
engaged.

\section{Perspective of}

Teacher

"Those girls don't like science."

\section{Assertion}

Student experiences are different when using e-textiles

\section{Student Comment/ Member} Check

"I don't like science. But this is art." 


\begin{abstract}
Kai struggled to focus or engage during introductory (non-etextiles) class. She was more focused on her goal of finishing her bracelet; she was the first in her class to complete the project.

Jessi asked to take her project home.
\end{abstract}

\section{Kai spent recess in the e- textiles classroom working on her bracelet. She chatted the entire time with her teacher. She spoke at length about a story from her native culture.}

Kai argued repeatedly with non-textiles teachers. She did not argue during e-textiles with any instructor. At one point, she hugged both teacher and the researcher and called them a native word that means family.

Jessi clapped when she found out she got to do another e-textiles project.
"She seems excited, but let's just see how she does. She is good, but extra work isn't her thing."
"She is always like this, struggling to do her work. But then she got so into it."
Student experiences are different with etextiles

"That is the first time she has done that."

"I had her all last year, and I can promise you she has never wanted to keep working on something. I am blown away!"

"Kai is really difficult. She is going to be hard on all her teachers for the rest of middle school. At least with this she talked to me."
Student experiences are different with etextiles
"This is great. I love it. I don't want it to end."
"This is kinda the first homework I can share with my mom. She will love it and help me."

\section{Student experiences} are different with etextiles.

Students and teachers talk differently with etextiles.

\section{Students and} teachers talk over etextiles.

Students and teachers talk differently with etextiles.
"I would rather stay with you guys. This is fun and we can tell stories."
"I hate her [the teacher from another class]. She is mean. She doesn't care. She just wants to control us. You heard her. She lies. She isn't like you and Ms. Massada. You guys are [Indigenous concept expressing the idea of family and cooperation]."
Student experiences are different $w$ etextiles
"This is so fun. I would do it even if I didn't need to for school."

\section{Findings}

Several key dynamics became evident as time went on within Jessi and Kai's classes. We noticed that non-dominant students behaved differently than their teachers expected. Cases present each focal student's experience as triangulated between their statements, our observations of their actions, and their teacher's assertions and perspectives. From these cases came an evidentiary warrant for two assertions. First, Jessi and Kai experienced e-textiles activities differently from other activities in their "normal" science classes. Second, Jessi and Kai found more opportunities to talk with their teachers over e-textiles than during other lessons. 
Jessi

Jessi attended a school where she was part of a large Latinx minority and often felt as if she did not belong in school, especially not in science. She often positioned herself as not very good at science, and her teacher supported this positioning. While her teacher, Ms. Lazel, described her as quiet, she frequently sought out the research team to chat during class. Prior to starting the e-textiles unit, the class spent two days on electricity projects unrelated to e-textiles. During this time, we asked Jessi about her experiences at CCMS and with her teachers. Jessi responded, "So, don't tell anyone, but I don't like it here. It's really hard to feel good. There are a lot of kids that are really rich and the teachers treat them like they are better than us poor kids. My parents don't really speak a lot of English. But the teachers don't care." Jessi emphasized the discrimination she and her fellow Latinx students faced at school, as well as the low expectations placed upon her by her teachers. Asked about her teachers' perceptions of her as a successful student, Jessi responded, "They [the teachers] mean 'for a Latin girl." When pressed, Jessi discussed how the White and Latinx students did not spend time together. For instance, she observed that none of the White and Latinx students worked together in groups. Her comments spoke to the level of in-school segregation that existed. She noted that teachers did not segregate students, but rather groups of students kept to themselves. Further into the conversation, Jessi identified herself as a poor science student and noted that her teacher could confirm her lack of ability. Referring to her science teacher, she stated, "Ask Ms. L. She will tell you. I can't do science. It is my lowest grade. I don't want to even take it anymore." In this comment, Jessi emphasized the ways in which she positioned herself and was positioned by others to believe that she could not take on a positive STEM identity.

During two days of classroom observations related to the non-e-textiles activities around circuitry, students in Jessi's class were provided with a series of assignments. Students could choose from three hands-on learning activities and three readings; each activity was assigned 10 points and students needed to complete 30 points worth of work. Jessi, like many of the Latina students in the class, opted to do the three readings. When queried about it, she replied, "Like I said, I am no good at science. I won't be able to get those things to work." However, we noted that the available activity choices ranged from highly complex to incredibly simplistic. While students needed to build an electroscope in one activity, another involved rubbing a ruler on cloth and then running it through paper punches from a hole punch to observe the change in static electric charge. Of the over 30 students observed, none were able to make the electroscope work because the teacher had not provided the proper materials for the project. Alternately, all of the nearly 50 students who attempted the ruler project were successful in the electron transfer. For Jessi, her beliefs about science ability negatively impacted her willingness to attempt scientific inquiry.

As the class moved into the mandatory e-textiles projects, we asked Jessi how she felt about trying hands-on science and she replied, "Oh this is fine. It's art!" For Jessi, etextiles presented as "not science" and, as such, were a relatively safer space for engagement. When pressed on her assertion that her e-textiles work was only art, she noted, "Ok, yeah, it's a circuit, but really it's sewing. Science stuff is, like, on paper." Her 
concept of school science was tied deeply to classwork on paper. Yet, when asked whether the experiments from the previous days were science, she agreed those were science.

As work on the e-textiles projects proceeded, Jessi began to speak more freely. She talked with other students in class about the assignments. She also engaged her teacher more in discussing her projects. In the first two days when there was no e-textiles instruction, Jessi did not talk with her teacher at all. In contrast, during her e-textiles work she was much more engaged with class and small group discussion. At one point, a classmate asked her for help and Jessi, referring to locating loose ends of thread or overlapping negative and positive lines of thread that can cause a short circuit in e-textiles projects, said, "Oh I can help! I am good at finding the shorts!" When we interviewed Ms. Lazel to inquire about any noted differences between Jessi's work during e-textiles and other science class activities, her teacher stated:

This was great for her and the girls like her. Normally, girls like her don't do science. But she was engaged more than any other time this year. She also talked a lot more. I think she liked it, because it was more artistic. Usually she does a good job in class, but it's not like she does an extra job. She does not do any of the extra credit.

Both Jessi and her teacher felt she was more engaged working with e-textiles projects. Based on the time we were able to observe her engaged in learning science without etextiles, our observations confirm this assertion. However, none of these data sources explicate the causes of this shift in behavior and engagement. Of additional note was the decision on Jessi's part to take her projects home to work on with her mother. Ms. Lazel noted that this had not happened previously, but Jessi's e-textiles work inspired her decision to do so.

\section{Kai}

Described by several teachers as "difficult" or "challenging," Kai did not cede arguments to adults gracefully. Frequently, we watched her argue with teachers of other classes. One day, she came to the e-textiles classroom to spend what she said was her free time; within 15 minutes another teacher entered the classroom screaming for her, as Kai had left her class without cleaning up. What then occurred was a classic teenage power struggle. Kai appeared unwilling to lose face in front of her peers and called the teacher a liar, resulting in her ultimately being referred to the administrator for disciplinary action.

When queried about Kai, Ms. Massada, who taught her during the e-textiles summer school class and during the previous school year noted, "She is so tough. She is going to be hard for all her teachers for the next few years. I am glad I got her before seventh grade, because now she is really going to be hard." Further discussion indicated that Kai was not a strong student by conventional academic measures of success, having received several low grades the prior year. Kai's disengagement and discomfort with the school system were visible on her first day of the e-textiles unit, when students were working on making their own paper circuits. While she completed the activities quickly 
and with ease, she demonstrated no interest. Her class's late arrival meant that the artistic aspects of paper circuits were truncated, with most time and focus being on learning the types of circuits. She said, "This is super boring," and rolled her eyes when the teacher informed her she could take her paper circuit home; she promptly recycled it. However, the following day, her mood and tenor shifted with the bracelet project. Nearly immediately upon seeing the model projects, she became enamored with her teacher's design of a volcanic eruption. Quickly, she sketched out her artistic design for making her own intricate bracelet. Surprisingly, she then quickly designed a circuit map that met her aesthetic design goals. She was the first student to begin to sew her project, and by the end of the first day, her circuit was nearly functional. When asked about the sudden progress, Ms. Massada quipped, "It's not like her. She was focused and sweet to everyone."

The following day, Kai was the first student in the door after recess. That day, she finished her circuit construction and immediately set about adding the artistic elements of her bracelet. During this period, she chatted and shared personal stories of her life-most notably of the death of a close relative. Her teacher engaged her on the topic and shared a quiet conversation with her as they both sewed. On the third and final day of the bracelet project, Kai opted to come early and work through recess so she could "get the whole thing done." As she worked, she again chatted with her teacher and also the researcher. When asked about why she was behaving so differently in this class than in some other classes, she said, "This is different. You guys care. They don't. But, like, you talk to me and don't get mad." When asked, Ms. Massada stated, "It's funny she thinks that I like her more now. I tried to build a relationship with her all last year but she just rolled her eyes." Kai explained her change of heart by saying, "Now I know [she] cares; not about some dumb worksheet or standard. I got to talk [about me]." In this way, we see how opening up spaces for personalizable projects and art within the science classroom can lead to shifts in how students see themselves and how they are perceived by others.

\section{Discussion}

The two cases we present highlight how integrating e-textiles into core content classes can provide access to, engagement with, and meaningful use of technology. Jessi and Kai both accessed e-textiles materials and activities in their science classes, where both were initially positioned as less than ideal students of science. While Jessi was widely perceived as a good student, she positioned herself and was positioned by others as "bad at science." Prior to the e-textiles unit, she had steered away from inquiry-driven activities, favoring reading assignments with clear right answers. In contrast, she saw etextiles as art and connected with the project. She was also able to share the project with her mom at home; the scientific aspects were secondary. One important lesson here is that students who believe themselves "bad at science" are unlikely to access science outside of schools, so providing access to multiple ways of doing science in schools is crucial. Making activities offer one alternative pathway into science education if they privilege alternative ways of knowing about and doing science. For instance, Jessi's experience of e-textiles engagement resonates with the work of many professional 
scientists who marvel at the aesthetic aspects of their work (Girod, 2007; Girod, Twyman, \& Wojcikiewicz, 2010; Resnick, Berg, \& Eisenberg, 2000) and with the Next Generation Science Standards, which emphasize a need to connect science education to professional disciplinary practice (NSB, 2013). Similarly, while Kai was widely perceived as a challenging student at her school, she engaged with e-textiles materials when given the space to make a personally meaningful design and talk about herself. The e-textiles unit allowed Kai an opportunity to share personal life stories and establish a relationship of caring with her teacher (Rolón-Dow, 2005). In this way, Kai was producing technology that was used for relationship building with her teacher, something she saw as meaningful.

Educators have long recognized the power of using technology for personal expression in literacy contexts (e.g., Hull \& Nelson, 2005; Black, 2008), but the idea of science as a means of self-expression is relatively new in educational contexts (Brennan \& Resnick, 2012). Writing about the power of youth-produced digital stories, Hull and Nelson (2005) state:

We believe that the increasingly multiplex ways by which people can make meaning in the world, both productively and receptively, can potentially represent a democratizing force whereby the views and values of more people than ever before can be incorporated into the ever-changing design of our world. (p. 226)

Similarly, e-textiles afford visual modes of expression and provide an opportunity to reflect on the business as usual of school science. How might we incorporate Indigenous (Cajete, 1999; Medin \& Bang, 2014), feminist, and aesthetic perspectives on science? How might we design learning experiences like e-textiles that incorporate students' and families' funds of knowledge?

In Kai's e-textiles experience, craft materials provided a point of entry, but storytelling and relationship building were the key features. For Jessi, it was less about being heard in the school classroom and more about being recognized at home.

Out of Jessi and Kai's experiences with e-textiles materials, we see several implications for practice. First, in science as elsewhere, educators should seek multiple points of connection to students' interests and identities. For Jessi and Kai, art and story were the hooks, but this may not be true for all students. In other e-textiles research (e.g., Searle \& Kafai, 2015a), students found points of connection through working on cars with their parents or through the experience of programming a project. The important commonality is that science is situated as personally meaningful and connected to one's life outside of school. Second, science educators should try to draw upon projects with multiple possible solutions. While Jessi was intimidated by hands-on science activities where she thought she would get the wrong answer, she enjoyed the process of finding short circuits, or debugging projects. If we think about the NGSS goal of making school science approximate professional practice, we realize that scientists rarely have all the answers and frequently grapple with the unknown. By moving beyond the idea of a single right answer, educators open up spaces for students' multiple, intersectional identities in classrooms. Finally, incorporating hands-on, inquiry-driven making activities may require some compromises to address standards alignment, but such activities open up spaces 
of possibility for girls and non-dominant students to begin to identify, if not with school science, then at least with STEM writ large.

\section{Notes}

1. Practitioners interested in more details on the projects are encouraged to read: Tofel-Grehl, C., Litts, B., \& Searle, K. (2016). Getting crafty with NGSS: Using Crafty Circuits to teach electricity in elementary school. Science and Children, 54(4), 48-53.

\section{Acknowledgments}

This work is supported by the National Science Foundation (Award \# 1542801). The views presented in this article are the authors' own and do not necessarily represent the views of Utah State University or the National Science Foundation.

\section{References}

Acholonu, U., Pinkard, N., \& Martin, C. K. (2015, June). Locating opportunity gaps by mapping the computer science landscape in Chicago. Paper presented at the Digital Media and Learning Conference, Los Angeles, CA.

Anyon, J. (1981). Social class and school knowledge. Curriculum Inquiry, 11(1), 3-42.

Archer, L., DeWitt, J., Osborne, J., Dillon, J., Willis, B., \& Wong, B. (2012). Science aspirations, capital, and family habitus: How families shape children's engagement and identification with science. American Educational Research Journal, 49, 881-908.

Barron, B., Gomez, K., Pinkard, N., \& Martin, C. K. (2014). The Digital Youth Network: Cultivating digital media citizenship in urban communities. Cambridge, MA: The MIT Press.

Bell, P., Van Horne, K., \& Cheng, B. H. (2017). Special issue: Designing learning environments for equitable disciplinary identification. Journal of the Learning Sciences, 26(3), 367-375. doi: 10.1080/10508406.2017.1336021

Black, R. W. (2008). Adolescents and online fan fiction. New York, NY: Peter Lang.

Blikstein, P., Kabayadondo, Z., Martin, A., \& Fields, D.A. (2017). An assessment instrument of technological literacies in makerspaces and FabLabs. Journal of Engineering Education, 106(1), 149-175.

Bourdieu, P. (1977). Outline of a theory of practice. New York, NY: Cambridge University Press.

Brayboy, B. M., \& Deyhle, D. (2000). Insider-outsider: Researchers in American Indian communities. Theory into Practice, 39(3), 163-169. 
Brennan, K., \& Resnick, M. (2012, April). New frameworks for studying and assessing the development of computational thinking. Paper presented at the annual meeting of the American Educational Research Association, Vancouver, British Columbia.

Buechley, L. (2006). A construction kit for electronic textiles. Proceedings of the IEEE International Symposium on Wearable Computers (ISWC), 83-90.

Buendia, E., Ares, N., Juarez, B., \& Peercy, M. (2004). The geographies of difference: The production of the East Side, West Side, and Central City School. American Educational Research Journal, 41(4), 833-865.

Cajete, G. A. (1999). Native science: Natural laws of interdependence. Santa Fe, NM: Clearlight Publishers.

Calabrese Barton, A., Tan, E., \& Greenberg, D. (2017). The Makerspace Movement: Sites of possibilities for equitable opportunities to engage underrepresented youth in STEM. Teachers College Record, 119(6), 1- 44.

Computer Science Teachers Association. (2017). K-12 Computer Science Standards, revised 2017. Retrieved from https://www.doe.k12.de.us/cms/lib/DE01922744/ Centricity/Domain/176/CSTA\%20Computer\%20Science\%20Standards\%20Revis ed\%202017.pdf

Craft, C. (2015, April). Keynote address. Utah State University Makers and Making Conference. Logan, Utah.

Cuban, L. (2001). Oversold and underused: Computers in the classroom. Cambridge, MA: Harvard University Press.

Davidson, D., \& Miller, K. (1998). An ethnoscience approach to curriculum issues for American Indian students. School Science and Mathematics, 98(5), 260-265.

DiSalvo, B., Reid, C., \& Roshan, P. K. (2014). They can't find us: The search for informal CS education. In Proceedings of SIGCSE 2014. Atlanta, GA: Association for Computing Machinery.

Eglash, R., Bennett, A., O'Donnell, C., Jennings, S., \& Cintorino, M. (2006). Culturally situated design tools: Ethnocomputing from field site to classroom. American Anthropologist, 108(2), 347-362.

Eglash, R., Gilbert, J., \& Foster, E. (2013). Broadening participation: Toward culturally responsive computing education. Communications of the ACM, 56(7), 33-36.

Emerson, R. M., Fretz, R. I., \& Shaw, L. L. (2011). Writing ethnographic fieldnotes (2 ed.). Chicago, IL: University of Chicago Press.

Ensmenger, N. (2010). The computer boys take over. Cambridge, MA: MIT Press.

Erickson, F. (1986). Qualitative methods in research on teaching. In M. Wittrock (Ed.), Handbook of research on teaching (3rd ed.) (pp. 119-161). New York, NY: MacMillan.

Fields, D. A., Kafai, Y. B., Nakajima, T. M., Goode, J., \& Margolis, J. (2018). Putting making into high school computer science classrooms: Promoting equity in 
teaching and learning with electronic textiles in Exploring Computer Science. Equity \& Excellence in Education, 51(1), 21-35.

Gay, G. (2000). Culturally responsive teaching: Theory, research, and practice. New York, NY: Teachers College Press.

Girod, M. (2007). A conceptual overview of the role of beauty and aesthetics in science and science education. Studies in Science Education, 43, 38-61

Girod, M., Twyman, T., \& Wojcikiewicz, S. (2010). Teaching and learning science for transformative aesthetic experience. Journal of Science Teacher Education, 21(7), 801-824.

González, N., Moll, L., \& Amanti, C. (2005). Funds of knowledge. New York, NY: Routledge.

Hammersley, M., \& Atkinson, P. (2007). Ethnography: Principles in practice (3 ed.). New York, NY: Routledge.

Hoffman, J., Bertot, J. C., \& Davis, D. M. (2012, June). Libraries connect communities: Public library funding \& technology access study 2011-2012. Digital supplement of American Libraries Magazine. Retrieved from http://viewer.zmags.com/ publication/4673a369

Holland, D., \& Lave, J. (2001). History in person: An introduction. In D. Holland \& J. Lave, History in person: Enduring struggles, contentious practice, intimate identities (pp. 3-33). Santa Fe, NM: School of American Research Press.

Horrigan, J. B. (2016, September). Libraries 2016. Washington, D.C.: Pew Research Center. Retrieved from http://assets.pewresearch.org/wp-content/uploads/ sites/14/2016/09/PI_2016.09.09_Libraries-2016_FINAL.pdf

Hull, G. A., \& Nelson, M. E. (2005). Locating the semiotic power of multimodality. Written Communication, 22(2), 224-261.

Kafai, Y. B., \& Burke, W. Q. (2014). Connected code. Cambridge, MA: Massachusetts Institute of Technology Press.

Kafai, Y. B., Fields, D. A., \& Searle, K. A. (2014). Electronic textiles as disruptive designs: Supporting maker activities in schools. Harvard Educational Review, 84(4), 532556.

Klug, B. J., \& Whitfield, P. T. (2003). Widening the circle: Culturally relevant pedagogy for American Indian children. New York, NY: Routledge.

Klump, J., \& McNeir, G. (2005). Culturally responsive practices for student success: $A$ regional sampler. Chicago, IL: Northwest Regional Educational Laboratory.

Margolis, J. Estella, R., Goode, J., Holme, J., \& Nao, K. (2008). Stuck in the shallow end: Education, race, and computing. Cambridge, MA: MIT Press.

Margolis, J., Ryoo, J. J., Sandoval, C. D. M., Lee, C., Goode, J., \& Chapman, G. (2012). Beyond access: Broadening participation in high school computer science. ACM Inroads, 3(4), 72-78. 
Medin, D. L. \& Bang, M. (2014). Who's asking? Native science, western science, and science education. Cambridge, MA: MIT Press.

National Science Board. (2013). Next generation science standards: For states, by states. Washington, DC: The National Academies Press. Retrieved from http://www.nextgenscience.org/sites/default/files/Appendix\%20F\%20\%20Science $\% 20$ and $\% 20$ Engineering $\% 20$ Practices $\% 20$ in $\% 20$ the $\% 20$ NGSS $\% 20$ \%20FINAL\%20060513.pdf

Oldenziel, R. (1999). Making technology masculine: Men, women, and modern machines in America. Amsterdam, The Netherlands: Amsterdam University Press.

Papert, S. (1980). Mindstorms. New York, NY: Basic Books.

Peppler, K., Halverson, E. R., \& Kafai, Y. B. (2016a). Makeology: Makerspaces as learning environments (Vol. 1). New York, NY: Routledge.

Peppler, K., Halverson, E. R., \& Kafai, Y. B. (2016b). Makeology: Makers as learners (Vol. 2). New York, NY: Routledge.

Perrin, A., \& Duggan, A. (2015). Americans' internet access: 2000-2015: Pew Research Center. Retrieved from http://www.pewinternet.org/2015/06/26/americansinternet-access-2000-2015/

Pinkard, N., Erete, S., Martin, C. K., \& McKinney de Royston, M. (2017). Digital youth divas: Exploring narrative-driven curriculum to spark middle school girls' interest in computational activities. Journal of the Learning Sciences, 26(3), 477-516.

Resnick, M., Berg, R., \& Eisenberg, M. (2000). Beyond black boxes: Bringing transparency and aesthetics back to scientific investigation. Journal of the Learning Sciences, 9(1), 7-30.

Rolón-Dow, R. (2005). Critical care: A color(full) analysis of care narratives in the schooling experiences of Puerto Rican girls. Anthropology \& Education Quarterly, 42(1), 77-111.

Rose, M. (2005). The mind at work. New York, NY: Penguin Books.

Scott, K. A., Sheridan, K. M., \& Clark, K. (2015). Culturally responsive computing: A theory revisited. Learning, Media, and Technology, 40(4), 412-436.

Searle, K. A., \& Kafai, Y. B. (2015a). Boys' needlework: Understanding gendered and indigenous perspectives on computing and crafting with electronic textiles. In Proceedings of the Eleventh Annual International Conference on International Computing Education Research (pp. 31-39). Omaha, NB: Association for Computing Machinery. Retrieved from http://dl.acm.org/citation. cfm?id=2787724

Searle, K. A., \& Kafai, Y. B. (2015b). Culturally responsive making with American Indian girls: Bridging the identity gap in crafting and computing with electronic textiles. In Proceedings of Gender and Information Technology 2015. Philadelphia, PA: Association of Computing Machinery. 
Searle, K. A., Tofel-Grehl, C., \& Allan, V. (2016). The e-textiles bracelet hack: Bringing making to middle school classrooms. In Proceedings of FabLearn. Palo Alto, CA: Association of Computing Machinery.

Stake, R. E. (1995). The art of case study research. Thousand Oaks, CA: SAGE.

Tan, E., Calabrese Barton, A., Kang, H., \& O'Neill, T. (2013). Desiring a career in STEMrelated fields: How middle school girls articulate and negotiate identities-in-practice in science. Journal of Research in Science Teaching, 50(10), 1143-1179.

Tofel-Grehl, C., Fields, D.A., Searle, K. A., Maahs-Fladung, C., Feldon, D., Gu, G., \& Sun, C. (2017). Electrifying engagement in middle school science class: Improving student interest through e-textiles. Journal of Science Education and Technology, 26, 406-417.

Tofel-Grehl, C., Searle, K. A., \& Feldon, D. F. (2018). Professional development for secondary science teachers: A faded scaffolding approach to preparing teachers to integrate computing. Proceedings of the $13^{\text {th }}$ International Conference of the Learning Sciences. London, UK.

Vossoughi, S., Hooper, P., \& Escude, M. (2016). Making through the lens of culture and power: Towards transformative visions for educational equity. Harvard Educational Review, 86(2), 206-232.

Warschauer, M., \& Matuchniak, T. (2010). New technology and digital worlds: Analyzing evidence of equity in access, use, and outcomes. Review of Research in Education, 34(1), 179-225.

Wolcott, H. F. (1999). Ethnography: A way of seeing. Lanham, MD: Altamira Press.

Yin, R. K. (2018). Case study research and applications (6th ed.). Los Angeles, CA: SAGE.

\section{Author Contact}

Kristin A. Searle: Kristin.searle@usu.edu

Department of Instructional Technology and Learning Science, Utah State University, 2830 Old Main Hill, EDUC 209, Logan, UT 84322

Colby Tofel-Grehl, Colby.tg@usu.edu

Department of Teacher Education and Leadership, Utah State University, 2830 Old Main Hill, EDUC 209, Logan, UT 84322

Janet Breitenstein, janet.breitenstein@aggiemail.usu.edu

Department of Teacher Education and Leadership, Utah State University, 2830 Old Main Hill, EDUC 209, Logan, UT 84322 